Article

\title{
Does Environmental Regulation Repress the International R\&D Spillover Effect? Evidence from China
}

\author{
Chengliang Liu ${ }^{1,2,3}{ }^{(\mathbb{C}}$, Tao Wang ${ }^{1}$ and Qingbin Guo ${ }^{4, *}$ \\ 1 School of Urban and Regional Sciences, East China Normal University, Shanghai 200062, China \\ 2 Institute for Global Innovation and Development, East China Normal University, Shanghai 200062, China \\ 3 Institute of Eco-Chongming, East China Normal University, Shanghai 200062, China \\ 4 School of Economics, Hainan University, Haikou 570228, China \\ * Correspondence: gqbhust@aliyun.com
}

Received: 30 June 2019; Accepted: 6 August 2019; Published: 12 August 2019

\begin{abstract}
The inconsistent direction between environmental regulation and technological progress is receiving increasing attention, but scholars have neglected the relationship between the two in the open economy. Against this background and based on the panel data of 30 provinces in China from 2003 to 2015, we examined the effect of environmental regulation on the international research and development (R\&D) spillover effect and its regional differences in three economic regions: The Bohai Rim, Pan-Yangtze River Delta, and Pan-Pearl River Delta economic regions. The results show that (1) at China's macro level, and at that of the three economic regions, the level of environmental regulation and international $R \& D$ spillover from import trade or foreign direct investment channels show an inverted $\mathrm{N}$ relationship; that is, in all provinces the weak environmental regulation initially inhibited the international technology spillover. However, as the intensity of environmental regulation increased, the level of international R\&D spillovers continually rose, but overly harsh environmental regulation was not conducive to the overflow of international technology; (2) the adoption of different environmental regulations will affect the international R\&D spillover effect and the inverted $\mathrm{N}$ relationship of environmental regulation, thus changing the inflection point of environmental regulation; and (3) currently, the level of environmental regulation is relatively low, as most provinces have not yet broken through the first turning point of the inverted $\mathrm{N}$, and only a few provinces are within the rising stage of the inverted $\mathrm{N}$ curve. This paper provides corresponding policy suggestions according to the above conclusions.
\end{abstract}

Keywords: environmental regulation; international trade; international R\&D spillovers; China

\section{Introduction}

Since the reform and opening up of China's economy in December 1978, the environmental problems caused by the country's extensive economic growth are attracting increasing global attention [1-3]. The signing of the International Framework Convention on Climate Change and the finalization of the Paris Agreement have shown that governments, while striving to increase the level of economic development, must also consider environmental protection [4-6]. Given the nature of environmental public goods, property rights are difficult to define, and the problem of negative externalization cannot be solved completely by relying solely on the market mechanism. Therefore, governments need to introduce a series of environmental policies to compensate for the defects of market failure. As an important institutional arrangement in China, environmental regulation can stimulate innovation mechanisms and may be used for innovation funds to restrain it [7]. Under the condition of an open economy, the technological progress of a region depends not only on technological 
innovation and research and development $(R \& D)$ investment, but also on the international R\&D spillover effect $[8,9]$. Many developing countries hope to learn of the advanced technology in developed countries through the international R\&D spillover effect and improve their technical level. In this context, whether environmental regulation will suppress the international R\&D spillover effect is a question worth exploring.

\subsection{Literature Review}

Since the 1970s, governments around the world have been strengthening their environmental regulations, and the influence of these environmental regulations on technological innovation have widely attracted attention from scholars. The traditional neoclassical economic theory holds that environmental regulation could improve the environmental protection level of a whole society and enhance the overall welfare, but it would increase the production costs of enterprises and inhibit technological innovation to a certain extent, such as the literature by Wanlley [10], in which it is argued that environmental regulation would not only increase production costs, thereby reducing corporate profits and leading to inadequate innovation, but additionally investment in pollution reduction and improving the quality of the enterprise would crowd out investment in promising projects and thus crowd out enterprise innovation. Unlike the traditional neoclassical economic theory, Porter and Linde [11] argued that a certain degree of environmental regulation could stimulate the regulated enterprise innovation, producing innovative compensation, reducing production costs, and improving product quality, so that domestic enterprises in the international market would have a competitive advantage, thus improving production efficiency. This argument, known as the "Porter Hypothesis", is explored in Ambec et al. [12] in both its theoretical foundations and empirical evidence. Using China's industry panel data, Han et al. [13] examined the "Porter Hypothesis" and found that environmental regulation had a positive effect on technological innovation. Concurrently, a certain threshold effect was found between environmental regulation intensity and R\&D technological progress; the two showed an inverted $U$ relationship. Only when the intensity of environmental regulation exceeded a certain threshold could the Porter hypothesis be established in China's industrial sector. Chakraborty and Chatterjee [14] estimated the indirect impact of environmental regulation on innovation activities of upstream (dye-producing) firms in India and found robust evidence of a significant increase (11-61\%) in innovation expenditure for the dye makers in response to the "Azo-dyes" ban. Meanwhile, some scholars think that the effect of environmental regulation on technological innovation is uncertain and might be positive or negative depending on the industrial structure, intensity of environmental regulation, and level of economic development. For example, Jaffe and Palmer [15] found that when industry factors were controlled, environmental regulation had a positive effect on R\&D spending. Ma and Cha [16] found, through empirical testing of the resource-based enterprises, that the impact of environmental regulation on technological innovation was mainly determined by the institutional environment. The command control environmental policy had no significant impact on the performance of the two aspects of technological innovation and ecological environment, and the incentives and resources based on environmental policy would promote enterprise innovation, improving the ecological environment. Dechezlepretre and Sato [17] found that environmental regulations induce innovation in clean technologies, but the resulting benefits do not appear to be sufficiently large to outweigh the costs of regulations for the regulated entities. Guo et al. [18] found that an inflection point exists in the role of environmental regulation in green technology innovation, and China is in the inhibition stage before the inflection point. Cohen and Tubb [19] agreed with the strong version of the Porter hypothesis whereby strict but flexible environmental regulations induce innovation and, over time, increase country-level competitiveness.

Scholars have also explored the impact of international R\&D spillovers on technological innovation from different perspectives. One of the most influential literature is Coe and Helpman [20], in which it is argued that with the increase in the degree of openness of a country, the international technology spillover effect of the import channel is more pronounced for its technological progress. Madsen [21], 
based on 16 OECD countries, studied the impact of international R\&D spillovers through the import trade channel on its technological advances, and found that R\&D spillovers from an import trade channel could significantly improve technological progress in these countries. Javorcik [22], based on firm-level data from Lithuania, produced evidence consistent with positive productivity spillovers from foreign direct investment (FDI) through contacts between foreign affiliates and their local suppliers in upstream sectors. The data indicated that spillovers are associated with projects with shared domestic and foreign ownership but not with fully owned foreign investments. Krammer [23], using a panel of 27 transition and 20 developed countries between 1990 and 2006, found that imports remained the main channel of diffusion for both sets of countries. FDI, although statistically significant, had less of an impact on the productivity of the recipients. Hassine et al. [24] investigated R\&D spillovers from inward foreign direct investment with respect to both horizontal and vertical linkages and found that international spillovers had a greater effect on firm performance than reverse spillovers and were more likely to be backward than forward. Zhuang and Zheng [25] found that the technological spillover effect of foreign capital in the service industry exists and could effectively improve China's technology progress and regional total factor productivity. However, the technology spillover effect differed across regions-it was significantly stronger in the eastern region compared to the mid-west region. Aldieri et al. [26] found, for the same level of absorptive capacity, that firms in economic areas that are closer to the world technology frontier tend to benefit more from pure (knowledge) spillovers than from rent spillovers. Lee [27] confirmed that R\&D investment and intermediate input import/export with technologically advanced economies play important roles in productivity growth in non-frontier countries, and the productivity gains of technology spillovers via input trade channels are likely larger for countries/industries where technology converges to the frontier.

In summary, most of the literature confirms that environmental regulation did have significant impacts on technological innovation. However, it is uncertain whether the international R\&D spillover effect, which was one of the effective methods of encouraging technological innovation, was affected by environmental regulation. Presently, research on this subject is lacking, and what has been reported has mainly focused on the study of the impact of environmental regulation on import and export and FDI from the perspective of international trade [28-32]. Therefore, compared with the literature, this paper is innovative in the following areas: (1) a focus on the impact of environmental regulation on the technology spillovers through both FDI and import trade and (2) most of the literature has grasped the relationship between environmental regulation and technological progress from the macro or industry level, but lack region-specific research. Therefore, we chose China as the research object and examined the impact of environmental regulation on international R\&D spillovers, providing corresponding suggestions. Some important tasks to achieve green and innovation-driven quality and efficiency in economic development include determining how to balance sustainable development and technological progress with environmental regulation below a certain level to promote industrial restructuring and upgrading. To this end, 30 provinces in China were the research objects for investigating the impact of environmental regulation on the international $R \& D$ spillover effect. This not only supplements the theoretical study of the effect of technological progress to improve the existing environmental regulations, but also drives innovation and green development for China while providing some theoretical support and policy recommendations for the strategic positioning of ecological protection and industrial development coordination.

\subsection{Defining Sustainable Development in the Context of Environmental Regulation and RED Activity}

As stated in the United Nations (UN) report Our Common Future, "sustainable development is development that meets the needs of the present without compromising the ability of future generations to meet their own needs". Reorienting technology and managing risk, such as environmental technology R\&D activity, and merging environment and economics in decision making, such as environmental regulation, are two important components of the report's proposed strategic imperatives. For the path of sustainable development in developing countries, the report proposed that technological innovation 
ability needs to be enhanced so that developing countries can better cope with the challenges of sustainable development. The orientation of technology development must be changed for addressing environmental challenges. One of the purposes of public policy is to motivate companies to develop or adopt more advanced environmental technologies.

Environmental regulation is a policy tool to promote the sustainable development of the economy, resources, and society. Its essence involves internalizing the social cost caused by enterprise pollution, promote energy conservation and emission reduction, accelerate technological innovation, and facilitate sustainable development while promoting technological progress. Technology R\&D can improve production methods and optimize industrial structure to provide technical support for sustainable development. Environmental regulation affects enterprise technology R\&D and impacts regional sustainable development. First, environmental regulation has forced companies to seek technological breakthroughs, forcing companies to provide green innovations in production technology. Second, the government providing clear standards for corporate emissions, while introducing preferential policies such as tax exemption and fee subsidies, supports the sustainable development of environmentally friendly enterprises. In the process of technological innovation and R\&D, enterprises are inevitably affected by the cost effect and compensation effect due to environmental regulation. The cost effect refers to the environmental regulations introduced by the government to impose restrictions on polluting enterprises, which increase the cost burden of enterprises and restrain their profit space. The compensation effect means that when enterprises are facing environmental regulations and cost pressures, they will actively conduct technological innovation to increase product competitiveness and create larger profits. When the compensation effect of environmental regulation can compensate for even more than the cost effect of enterprises, environmental regulation will actively promote enterprises to conduct technological innovation, reduce pollutant emissions, and promote regional sustainable development.

\section{Data and Model Construction}

\subsection{Data Sources and Variables}

The previous analysis showed that foreign research and development results enter China mainly through import trade and FDI channels. In this study, we first measured the international R\&D spillover effect through imports and FDI channels. Considering data availability, we chose the 2003-2015 period as a sample, the original data from the calendar year of the China Statistical Yearbook, China Environment Statistical Yearbook, World Investment Report, OECD Factbook, national research network database, CEIC database, World Development Indicators, and the databases of the local statistical yearbooks of all provinces in China.

Our research object was China and our purpose was to examine if environmental regulation represses the international R\&D spillover effect. There are 34 provincial administrative units in China. However, due to history or other reasons, the data of four provincial administrative units, Tibet, Taiwan, Hong Kong, and Macau, were relatively scarce or statistically inconsistent. To avoid the impact of these four administrative units on the overall calculation results, they were excluded from this study. Within this, the specific spatial scope of this study was 30 provincial-level administrative units in China (Figure 1). 


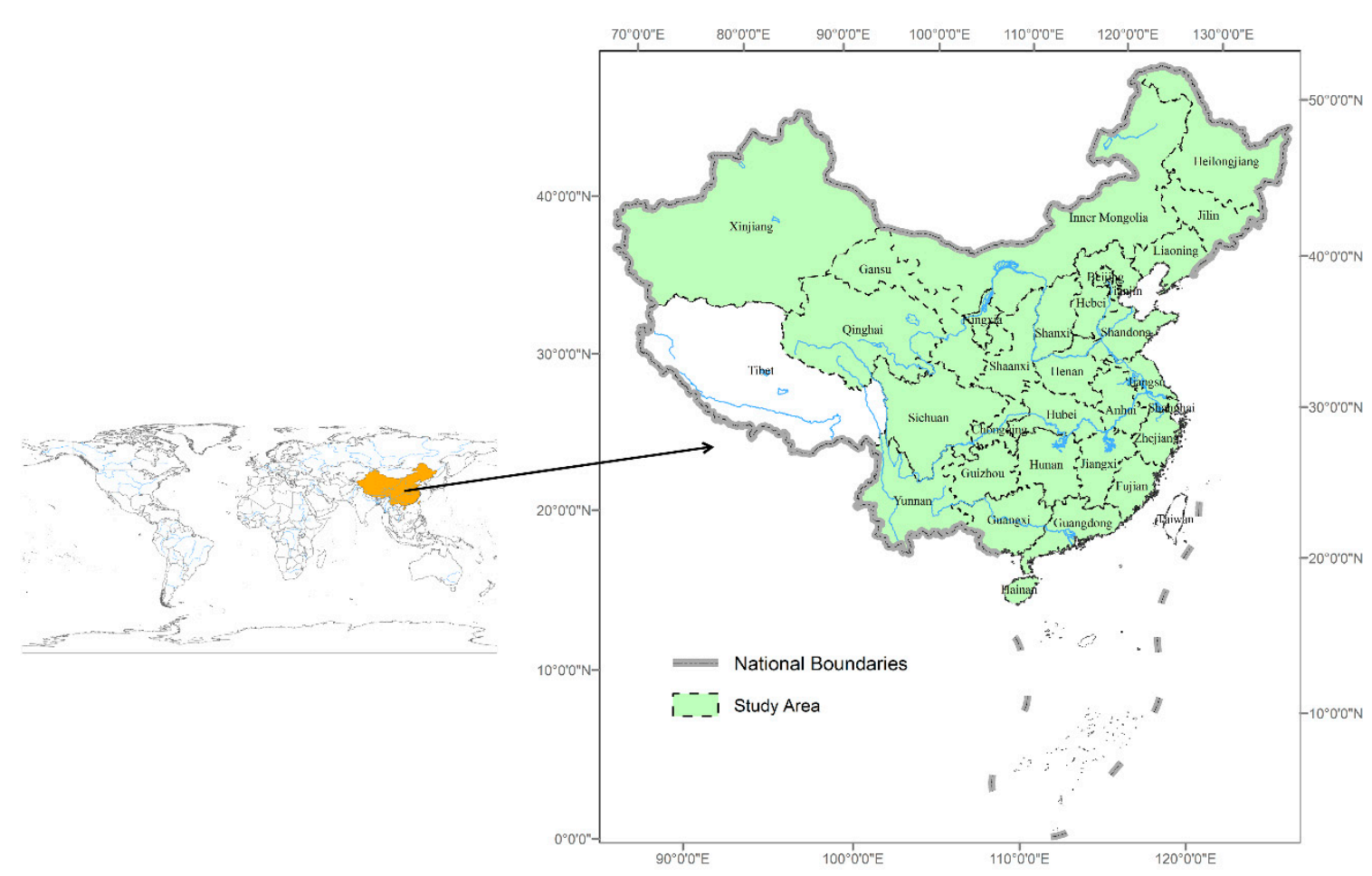

Figure 1. Study area.

\subsubsection{International R\&D Spillover Index}

For the source of international R\&D spillover stock, according to the main source of China's imports and FDI, the number of R\&D stocks in every country, selected G7 countries, and South Korea, Hong Kong, Singapore, China, plus the 10 countries or regions chosen as the research sample, we studied the international R\&D spillover effect based on import trade and FDI channels. Given the spillover of R\&D in these countries or regions, we used Lichtenberg and Potterie's [33] spillover measure to define international R\&D spillovers based on import trade channel, calculated as:

$$
I M S P_{i t}=\sum_{j \neq i} \frac{M_{i j t}}{Y_{j t}} S D_{j t}
$$

where $I M S P_{i t}$ is the international R\&D spillover that $i$ province obtained through the import trade channel in $t$ years, $M_{i j t}$ is the total import trade of the nation or region $j$ in $i$ provinces in the first $t$ years, $Y_{j t}$ is the GDP of the country or region $j$ in $t$ years, and $S D_{j t}$ is the domestic R\&D stock of nation or region $j$ in the first $t$ years.

On the basis of the model measured by Lichtenberg and Potterie [33], the international R\&D spillovers based on FDI channel are defined as:

$$
\text { FDISP }_{i t}=\sum_{j \neq i} \frac{F D I_{i j t}}{Y_{j t}} S D_{j t}
$$

where FDISP $P_{i t}$ is the amount of foreign R\&D capital spillovers of $i$ province in $t$ years through FDI channels and $F D I_{i j t}$ is the direct investment from the country or region $j$ to $i$ in $t$ years.

For the measurement of the domestic $R \& D$ stock of nation or region $j$, we used the perpetual inventory method $[34,35]$ to estimate, calculated as:

$$
S D_{t}=(1-\delta) S D_{t-1}+R D_{t}
$$


where $S D_{t}$ and $S D_{t-1}$ denote the depreciation rate of R\&D capital in the country or region at year $t$ and $t-1$ years, respectively, $\delta$ is the depreciation rate of R\&D capital (in this paper, we used $5 \%$ calculated by Coe and Helpman [20]), and $R D_{t}$ is the actual expenditure on the development of the fixed asset price index in the year 2003.

Since there are no statistical FDI data at the provincial and municipal levels of the source countries, the data that could be obtained were only the statistics of the importing countries of the provinces and municipalities. Given the convenience of data acquisition and calculation, we first calculated the stocks of imports and FDI channels at the national level in China according to Equations (1) and (2). Then, we used the import data of each province and city, the proportion of FDI in the national FDI, multiplied with IMSP and FDISP at the national level, to obtain the IMSP and FDISP of each province and city. We deflated the FDISP and IMSP series using the GDP deflator.

\subsubsection{Environmental Regulation Intensity's Index}

Environmental regulation, as a policy behavior according to the difference between regulatory means and the behavior affecting business, can be divided into command-controlled environment regulation, incentive-type environmental regulation, and voluntary environmental regulation. Among them, incentive-type environmental regulation occurs when the government treats the market as the carrier; guides enterprises' sewage behavior; reduces the level of sewage using the collection of sewage charges; supports emissions trading, subsidies, and other economic measures; and then gives the economy a certain degree of choice and action. The enterprise self-restraint mechanism is more operational than the voluntary basis, so we mainly studied the incentive regulation policy environment.

For measuring the strength of environmental regulation, scholars have used many indicators, such as Ryan [36], who measured this using two indicators: Expenditure of enterprises implementing environmental regulations, and expenditure from policy or social supervision and implementation of environmental regulation. Rubashkina et al. [37] selected the industrial wastewater discharge and industrial $\mathrm{SO}_{2}$ removal rates of two indicators to reflect the intensity of environmental regulation. Yin et al. [38] selected the proportion of income from regional sewage charges to GDP, and the proportion of investment into completed industrial pollution control projects to GDP, to represent the intensity of regional environmental regulation.

Based on the availability of data, the relative perfection of the indexes, and the measure method of Yin et al. [38], the intensity of environmental regulation can be measured from the two following aspects: The proportion of sewage fee income or area to GDP $\left(E R_{1}\right)$ and the proportion of investment into completed industrial pollution control projects to GDP $\left(\mathrm{ER}_{2}\right)$. The larger the values of the two indicators, the stronger the intensity of environmental regulation in the province or region.

\subsubsection{Measurement of Control Variables}

Human capital $(\mathrm{H})$ is expressed by the average number of years of education in various provinces and municipalities. Many scholars think that human capital is an important factor influencing environmental regulation and technological progress. For example, Zivin and Neidell [39] stated that environmental regulation promoting technological innovation must rely on certain human capital. The level of economic development (ED) in the region is measured by the real GDP per capita, calculated by the GDP deflator of each province over the time period. The higher the level of regional economic development, the greater the spillover effect of foreign capital, which is helpful for improving the level of innovation. Enterprise scale (SIZE) is expressed by the average assets of industrial enterprises above a designated size in China to investigate the impact of the size of the enterprise on the efficiency of its technological progress.

To study the quantitative characteristics of each variable as a whole, each variable is statistically described in Table 1. 
Table 1. Descriptive statistics of the variables.

\begin{tabular}{ccccc}
\hline Variable & Mean Value & Variance & Minimum Value & Maximum Value \\
\hline FDISP & 1.0184 & 1.0829 & 0.0044 & 5.5974 \\
IMSP & 1.0921 & 1.0521 & 0.0344 & 5.4957 \\
ER $_{1}$ & 0.0534 & 0.0470 & 0.0016 & 0.4831 \\
ER $_{2}$ & 0.1735 & 0.1396 & 0.0067 & 0.9919 \\
LnED & 0.6249 & 0.6337 & -0.9939 & 2.1408 \\
LnH & 0.0906 & 0.0594 & 0.0183 & 0.4121 \\
SIZE & 2.1581 & 1.6585 & 0.4907 & 10.6983 \\
\hline
\end{tabular}

\subsection{Model Construction}

Based on the research results reported by Han et al. [13] and Dechezlepretre and Sato [17], the environmental regulation and international R\&D spillover were found to have an inverted N-curve relationship. To study the relationship between environmental regulation and the international Chinese area experiencing the $R \& D$ spillover effect, we introduced the environmental regulation intensity as one, two, and three times, to reduce heteroscedasticity and some variables during logarithmic processing. We established the estimation model as follows:

$$
\begin{gathered}
\text { FDISP }_{i t}=\alpha_{0}+\alpha_{1} E R_{i t}+\alpha_{2} E R_{i t}^{2}+\alpha_{3} E R_{i t}^{3}+\alpha_{4} L n H_{i t}+\alpha_{5} L n E D_{i t}+\alpha_{6} S I Z E_{i t}+V_{i}+\varepsilon_{i t}, \\
I M S P_{i t}=\beta_{0}+\beta_{1} E R_{i t}+\beta_{2} E R_{i t}^{2}+\beta_{3} E R_{i t}^{3}+\beta_{4} L n H_{i t}+\beta_{5} L n E D_{i t}+\beta_{6} S I Z E_{i t}+Z_{i}+\delta_{i t},
\end{gathered}
$$

where $E R_{i t}$ is the environmental regulation intensity of $i$ province in year $t, H_{i t}$ is the human capital, $L n E D_{i t}$ is the level of economic development in the region, $S I Z E_{i t}$ is the ownership structure, $\alpha$ and $\beta$ are the parameters to be estimated, $V_{i}$ and $Z_{i}$ are individual effects, and $\varepsilon_{i t}$ and $\delta_{i t}$ are random error terms.

\section{Results}

\subsection{Macro-Level Impact}

First, the effects of environmental regulation intensity on FDISP and IMSP (Models 1 and 3 in Table 2, respectively) were examined by the environmental regulation intensity ER1, characterized by the collection of sewage charges. To test the robustness, the environmental regulation intensity ER2, characterized by the environmental pollution control project, was used simultaneously to create a regression test of the international R\&D spillovers. As the timespan of the panel data used in this paper was relatively short, and the unit root process was small, it was not necessary to consider the stability of time series. For short panel data, it is generally assumed that the random perturbation terms are independently identically distributed and have no autocorrelation.

Based on the 30 provinces' data from 2003 to 2015 in China, the results obtained by stata12.0 are shown in Table 2. 
Table 2. Results of environmental regulation on international R\&D spillovers.

\begin{tabular}{|c|c|c|c|c|c|c|c|c|}
\hline \multirow{2}{*}{ Variable } & \multicolumn{2}{|c|}{ Model 1 (FDISP) } & \multicolumn{2}{|c|}{ Model 2 (FDISP) } & \multicolumn{2}{|c|}{ Model 3 (IMSP) } & \multicolumn{2}{|c|}{ Model 4 (IMSP) } \\
\hline & Fixed Effect & Random Effect & Fixed Effect & Random Effect & Fixed Effect & Random Effect & Fixed Effect & Random Effect \\
\hline c & $\begin{array}{l}-2.1802 \\
(-1.54)\end{array}$ & $\begin{array}{l}-1.1858 \\
(-0.86)\end{array}$ & $\begin{array}{c}-3.4869 * * \\
(-2.56)\end{array}$ & $\begin{array}{c}-2.4185^{*} \\
(-1.82)\end{array}$ & $\begin{array}{l}-1.7437 \\
(-1.23)\end{array}$ & $\begin{array}{c}-0.7374 \\
(-0.54)\end{array}$ & $\begin{array}{c}-2.3872 * \\
(-1.78)\end{array}$ & $\begin{array}{l}-1.3726 \\
(-1.05)\end{array}$ \\
\hline $\mathrm{ER}_{1}$ & $\begin{array}{c}-10.5711 \text { *** } \\
(-3.82)\end{array}$ & $\begin{array}{c}-11.0064^{* * *} \\
(-4.01)\end{array}$ & & & $\begin{array}{c}-5.2587 * * \\
(-1.91)\end{array}$ & $\begin{array}{c}-5.4495^{* *} \\
(-2.00)\end{array}$ & & \\
\hline $\mathrm{ER}_{1}{ }^{2}$ & $\begin{array}{l}57.9141^{* * *} \\
\quad(-3.79)\end{array}$ & $\begin{array}{c}58.4501 * * * \\
(-3.83)\end{array}$ & & & $\begin{array}{c}31.8609^{* * *} \\
(-2.1)\end{array}$ & $\begin{array}{c}31.8572 * * \\
(-2.1)\end{array}$ & & \\
\hline $\mathrm{ER}_{\mathbf{1}}{ }^{3}$ & $\begin{array}{c}-81.1322 * * * \\
(-3.54)\end{array}$ & $\begin{array}{c}-80.9156^{* * *} \\
(-3.53)\end{array}$ & & & $\begin{array}{c}-47.7331^{* *} \\
-2.09\end{array}$ & $\begin{array}{c}-47.0848^{* *} \\
(-2.06)\end{array}$ & & \\
\hline LnED & $\begin{array}{c}0.7979 * * * \\
(8.34)\end{array}$ & $\begin{array}{c}0.8356^{* * *} \\
(8.82)\end{array}$ & $\begin{array}{c}0.8486^{* * *} \\
(8.85)\end{array}$ & $\begin{array}{c}0.8968^{* * *} \\
(9.44)\end{array}$ & $\begin{array}{c}0.9894^{* * *} \\
(10.39)\end{array}$ & $\begin{array}{c}1.0287^{* * *} \\
(10.94)\end{array}$ & $\begin{array}{c}1.0115^{* * *} \\
(10.73)\end{array}$ & $\begin{array}{c}1.0554^{* * *} \\
(11.35)\end{array}$ \\
\hline LnH & $\begin{array}{c}1.5273^{* *} \\
(2.27)\end{array}$ & $\begin{array}{l}1.0591 \\
(1.63)\end{array}$ & $\begin{array}{c}2.0455^{* * *} \\
(3.1)\end{array}$ & $\begin{array}{c}1.5270^{* *} \\
(2.38)\end{array}$ & $\begin{array}{c}1.2000 * \\
(1.79)\end{array}$ & $\begin{array}{l}0.7190 \\
(1.12)\end{array}$ & $\begin{array}{c}1.4629^{* *} \\
(2.25)\end{array}$ & $\begin{array}{l}0.9691 \\
(-1.54)\end{array}$ \\
\hline SIZE & $\begin{array}{c}-0.0956^{* * *} \\
(-4.67)\end{array}$ & $\begin{array}{c}-0.0954^{* * * *} \\
-4.78\end{array}$ & $\begin{array}{c}-0.1009 * * \\
(-2.56)\end{array}$ & $\begin{array}{c}-0.09939 * * * \\
(-4.89)\end{array}$ & $\begin{array}{c}-0.0811 * * * \\
(-3.98)\end{array}$ & $\begin{array}{c}-0.0791^{* * *} \\
(-4.00)\end{array}$ & $\begin{array}{c}-0.0836^{* * *} \\
(-4.09)\end{array}$ & $\begin{array}{c}-0.0812 \text { *** } \\
(-4.08)\end{array}$ \\
\hline $\mathrm{ER}_{2}$ & & & $\begin{array}{c}-1.8519^{* *} \\
(-2.14)\end{array}$ & $\begin{array}{c}-1.7435^{* *} \\
(-2.00)\end{array}$ & & & $\begin{array}{l}-1.2228 \\
(-1.44)\end{array}$ & $\begin{array}{c}-1.1134 \\
(-1.3)\end{array}$ \\
\hline $\mathrm{ER}_{2}{ }^{2}$ & & & $\begin{array}{c}4.2758^{*} \\
(1.78)\end{array}$ & $\begin{array}{l}3.8116 \\
(-1.57)\end{array}$ & & & $\begin{array}{c}3.547 \\
(1.5)\end{array}$ & $\begin{array}{l}3.1441 \\
(1.32)\end{array}$ \\
\hline $\mathrm{ER}_{2}{ }^{3}$ & & & $\begin{array}{c}-2.6916 \\
(-1.5)\end{array}$ & $\begin{array}{l}-2.33 \\
(-1.29)\end{array}$ & & & $\begin{array}{c}-2.3872 * * \\
(-1.78)\end{array}$ & $\begin{array}{l}-2.2138 \\
(-1.25)\end{array}$ \\
\hline Hausman & \multicolumn{2}{|c|}{0.0878} & \multicolumn{2}{|c|}{0.0343} & \multicolumn{2}{|c|}{0.0957} & \multicolumn{2}{|c|}{0.0873} \\
\hline$R^{2}$ & 0.5668 & 0.5661 & 0.5534 & 0.5525 & 0.6071 & 0.6065 & 0.6043 & 0.6036 \\
\hline F Test & $70.67^{* * *}$ & $425.79^{* * *}$ & $66.92 * *$ & $399.32 * * *$ & $83.44^{* * *}$ & $502.18^{* * *}$ & $82.48^{* * *}$ & $495.39 * * *$ \\
\hline$p$-Value & 0 & 0 & 0 & 0 & 0 & 0 & 0 & 0 \\
\hline $\begin{array}{c}\text { Inflection Point } \\
\text { Value }\end{array}$ & 0.1284 & 0.3532 & 0.3036 & 0.7555 & 0.1094 & 0.3355 & 0.2222 & 0.7683 \\
\hline
\end{tabular}

Note: ${ }^{* * *}, * * *$ denote significance at the $10 \%, 5 \%$, and $1 \%$ level, respectively; the value inside the parentheses is $T$; the unit of the inflection point value is $\%$. 
As shown in Table 2, the results of the Hausman test show that the four models are suitable for the fixed-effect model. In all models, the first term of the environmental regulation intensity is negative, the quadratic term is positive, and the cubic term is negative. This shows that the relationship between environmental regulation intensity and international R\&D spillover level was an inverted $\mathrm{N}$ curve. This also verified that the levels of international R\&D spillovers in various provinces of China decreased with the increase in environmental regulation first, rose with the increase in environmental regulation after the regulatory strength reaching the inflection point, and declined after breaking through the highest value that the enterprise could bear. In Models 1 and 3, the major variable coefficients passed the significance test at the $10 \%$ confidence level, which showed that the model fitting was good and had strong explanatory power. Although the statistical results were not significant for some variables in Models 2 and 4, the symbols of the first, quadratic, and cubic terms of environmental regulation were still negative, positive, and negative, respectively, which did not affect the judgment of the model. The result of the robustness test was consistent with the other two models, which further validated our conclusions.

From Model 1, for the international R\&D overflow from the FDI channel, the first and second inflection points of the environmental regulation level represented by the proportion of sewage charges to GDP were $0.1284 \%$ and $0.3532 \%$, respectively. When the proportion of sewage charges accounting for GDP is between $0.1284 \%$ and $0.3532 \%$, the charges effectively stimulate the international R\&D spillovers, but when less than $0.1284 \%$ or higher than $0.3532 \%$, the two were negatively correlated. From Model 3 , the environmental regulation intensities of the two inflection points for the import channel of the international R\&D overflow were $0.1094 \%$ and $0.3355 \%$, respectively. When the proportion of sewage charges accounting for GDP was between $0.1094 \%$ and $0.3355 \%$, environmental regulation could effectively promote trade spillovers in the import trade. However, judging from the previous descriptive statistics, the proportion of sewage charges accounting for regional GDP was $0.0534 \%$ in the studied provinces in China and was left of the first inflection point, indicating that the current level of overall environmental regulation was low. These charges undermined China's ecological environment and inhibited the local transformation of foreign R\&D results. This result showed that the implementation of strong environmental regulation of various regions in the short term might inhibit the spillover of technology in international trade, weakening the international R\&D spillover effect, but, in the long term, the appropriate level of environmental regulation would stimulate the absorption of foreign R\&D results in the country.

In contrast with the inflection point of environmental regulation in the model, the first inflection point value of the environmental regulation level represented by the proportion of sewage charges to GDP was lower than the first inflection point value of the environmental regulation level represented by industrial pollution control projects. It was more convenient for the rapid implementation of the inverted N-type curve to the rising stage of the enterprises in China, and the enterprises were environmentally regulated by collecting sewage charges, compared with the government's direct investment in pollution control. This indicates that the impact of different environmental regulations on the impact of international R\&D spillovers was significantly different.

All the models show that the regional development level (LnED) had a positive effect on international R\&D spillovers in the control variables, indicating that the level of economic development was high, the environmental protection awareness of enterprises and residents was stronger, and environmental regulation-related policies were also easier to implement, thus contributing to the promotion of innovation in international trade. Human capital $(\mathrm{H})$ could also boost the level of international R\&D spillovers. Human capital was an important factor for China to absorb foreign advanced technology and achieve local transformation. In particular, the professional quality and environmental quality of a higher educated labor force would enhance the level of regional technological innovation. Enterprise size (SIZE) had a significant negative effect on the technology spillovers in international trade, indicating that the firm size had a negative effect on productivity. The reason for 
this is probably that larger enterprises might be subject to the inherent mode of production and, to a certain extent, ignored the absorption of foreign advanced technology.

\subsection{Regional Level Impact}

To further analyze the relationship between regional environmental regulation and the international R\&D spillover effect, from the perspective of regional socio-economic development, we divided China's 30 provinces into three major economic regions: The Bohai Rim, the Pan-Yangtze River Delta, and the Pan-Pearl River Delta (Figure 2). According to Zhan and Yu's [40] classification method, the Bohai Rim region includes Beijing, Tianjin, Hebei, Shanxi, Inner Mongolia, Liaoning, Jilin, Heilongiiang, and Shandong; the Pan-Yangtze River Delta region includes Shanghai, Jiangsu, Zhejiang, Anhui, Henan, Shaanxi, Gansu Qinghai, Ningxia, and Xinjiang; and the Pan-Pearl River Delta region includes Fujian, Jiangxi, Hubei, Hunan, Guangdong, Guangxi, Hainan, Sichuan, Guizhou, Yunnan, and Chongqing.

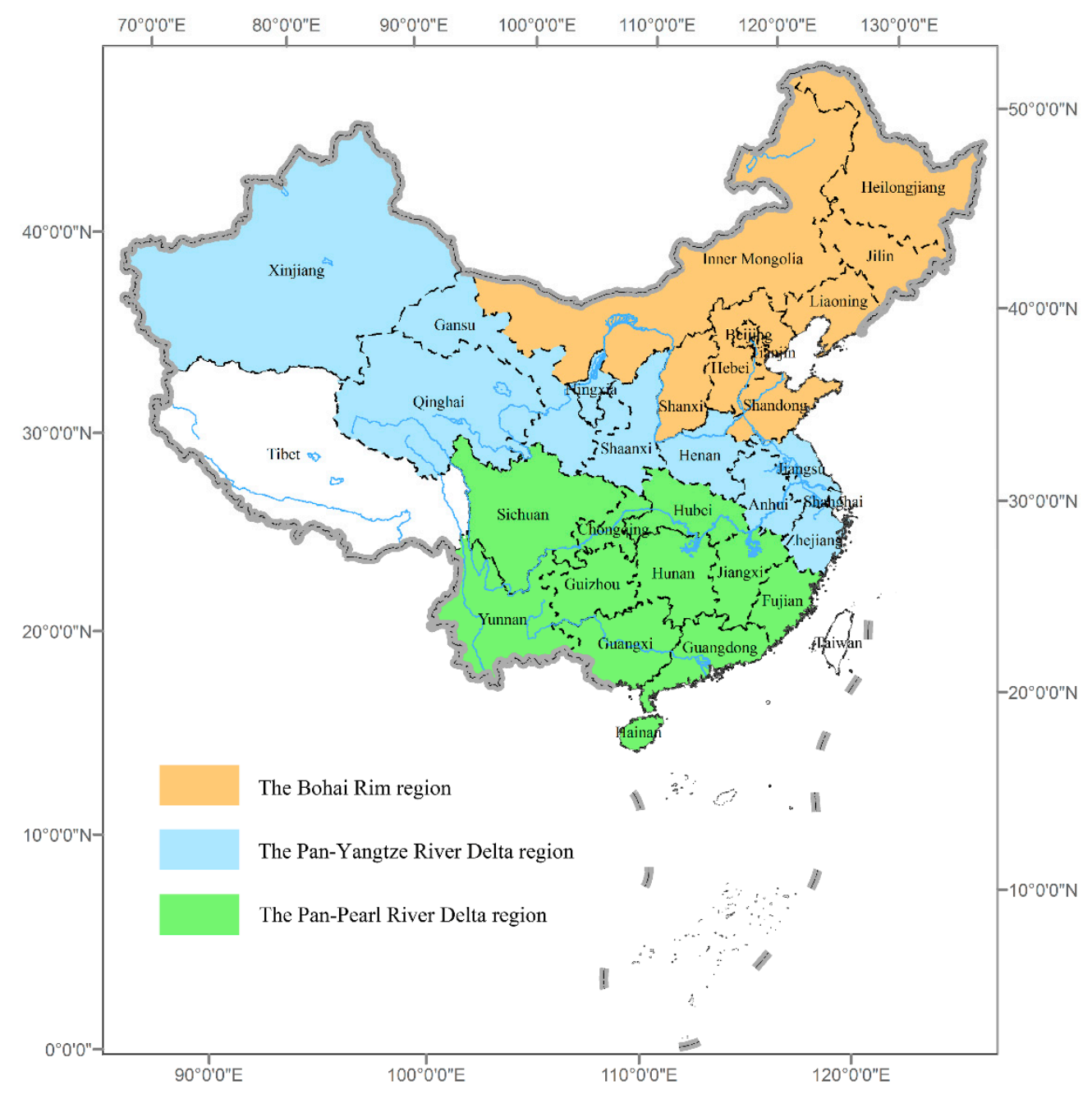

Figure 2. The division of three major economic regions in China.

Due to the availability of data, Tibet was excluded in this study. And because the previous analysis showed that the fixed-effect model is appropriate to use for analysis, in the sub-regional research we only used the fixed-effect model to analyze the three major economic circulation environmental regulations and the international R\&D spillover effect. The empirical results are provided in Tables 3-5.

Tables 3-5 show that in the three major economic regions, the first term of the intensity of the environmental regulation of most models is negative, the quadratic term is positive, and the cubic term is negative (only in Model 4 of the Bohai Rim region is the intensity of environmental regulation 
positive, positive, and negative one, two, and three times, respectively, but the coefficients are not significant. The intensity of environmental regulation and international R\&D overflow level are in an inverted N-type curve relationship, indicating that in both the national and sub-regional analysis, the level of international $R \& D$ spillover decreases with increasing environmental regulation. When the regulatory strength reaches the first inflection point, the R\&D spillovers also increase with the increase in environmental regulation. After breaking through the maximum value of the enterprise, the R\&D spillovers show a downward trend.

From the empirical sub-region results, the first inflection point in the model is characterized by the proportion of sewage charges to GDP. The first inflection point level is lower than the first inflection point value of the environmental regulation level represented by industrial pollution control projects, whether from inter-provincial or sub-regional analysis, compared to the government-funded pollution control. The enterprises are environmentally regulated by collection of sewage charges, which could be more conducive to the rapid realization of the inverted $\mathrm{N}$-type curve during the ascending stage of conversion. Also, different environmental regulations have significantly different impacts on international R\&D overflow.

Table 3. The Bohai Rim region's results.

\begin{tabular}{|c|c|c|c|c|}
\hline Variable & Model 1 (FDISP) & Model 2 (FDISP) & Model 3 (IMSP) & Model 4 (IMSP) \\
\hline c & $\begin{array}{c}-8.8179 * * \\
(-2.18)\end{array}$ & $\begin{array}{c}-9.7500 * * * \\
(-2.42)\end{array}$ & $\begin{array}{c}-9.6456^{* * *} \\
(-2.73)\end{array}$ & $\begin{array}{c}-9.4387^{* * *} \\
(2.72)\end{array}$ \\
\hline $\mathrm{ER}_{1}$ & $\begin{array}{c}-6.7358 \\
(-1.38)\end{array}$ & & $\begin{array}{c}6.9443 \\
(1.64) \\
\end{array}$ & \\
\hline $\mathrm{ER}_{1}{ }^{2}$ & $\begin{array}{c}30.7778 \\
(1.40)\end{array}$ & & $\begin{array}{c}-23.2967 \\
(-1.21)\end{array}$ & \\
\hline $\mathrm{ER}_{1}{ }^{3}$ & $\begin{array}{c}-39.5955 \\
(-1.32)\end{array}$ & & $\begin{array}{c}22.9528 \\
(0.88)\end{array}$ & \\
\hline LnED & $\begin{array}{c}0.5778^{* * *} \\
(3.15)\end{array}$ & $\begin{array}{c}0.8486^{* * *} \\
(8.85)\end{array}$ & $\begin{array}{c}1.0679 * * * \\
(6.68)\end{array}$ & $\begin{array}{c}1.0281 \text { *** } \\
(6.52)\end{array}$ \\
\hline LnH & $\begin{array}{c}4.4186^{* *} \\
(2.34)\end{array}$ & $\begin{array}{c}2.0455^{* * *} \\
(3.1)\end{array}$ & $\begin{array}{c}4.4280^{* * *} \\
(2.69)\end{array}$ & $\begin{array}{c}4.4202^{* * *} \\
(2.69)\end{array}$ \\
\hline SIZE & $\begin{array}{c}-0.0970 \text { ** } \\
(-2.51)\end{array}$ & $\begin{array}{c}-0.1009 \text { ** } \\
(-2.56)\end{array}$ & $\begin{array}{c}-0.0612^{* * * *} \\
(-3.98)\end{array}$ & $\begin{array}{c}-0.0632 \text { ** } \\
(-1.91)\end{array}$ \\
\hline $\mathrm{ER}_{2}$ & & $\begin{array}{c}-1.8356 \\
(-0.96)\end{array}$ & & $\begin{array}{c}0.8111 \\
(-0.49)\end{array}$ \\
\hline $\mathrm{ER}_{2}{ }^{2}$ & & $\begin{array}{l}4.3368 \\
(0.70)\end{array}$ & & $\begin{array}{c}0.3242 \\
(0.06)\end{array}$ \\
\hline $\mathrm{ER}_{2}{ }^{3}$ & & $\begin{array}{c}-3.0971 \\
(-0.55)\end{array}$ & & $\begin{array}{c}-1.2962 \\
(-0.27)\end{array}$ \\
\hline$R^{2}$ & 0.5498 & 0.5470 & 0.7579 & 0.7603 \\
\hline F Test & $18.93^{* * *}$ & $18.72^{* * *}$ & $48.51^{* * *}$ & $49.16^{* * *}$ \\
\hline$p$-Value & 0 & 0 & 0 & 0 \\
\hline Inflection Point & 0.1570 & 0.3243 & 0.4550 & 0.3809 \\
\hline Value & 0.3612 & 0.6093 & 0.2216 & -0.5476 \\
\hline
\end{tabular}

Note: ${ }^{* *}, * * *$ express significance at the $10 \%, 5 \%$, and $1 \%$ level, respectively; the value inside parentheses is the $T$ value; the unit of the inflection point value is $\%$.

Compared to the Pan-Yangtze River Delta and the Pan-Pearl River Delta economic regions, the Bohai Rim economic region in the two models of environmental regulation has a higher inflection point value. To achieve a win-win situation with environmental protection and absorption of foreign research and development results, a higher level of environmental regulation is necessary. 
Accordingly, enterprises in these areas can withstand more stringent environmental regulation policies. The Pan-Yangtze River Delta economic region and the Pan-Pearl River Delta economic region can quickly reach the ascending stage, and the corresponding inverted N-type curve's second inflection point will be more rapidly achieved. Therefore, a certain degree of difference exists between the regional environmental regulation and the international R\&D spillover effect.

Table 4. The Pan-Yangtze River Delta region's results.

\begin{tabular}{|c|c|c|c|c|}
\hline Variable & Model 1 (FDISP) & Model 2 (FDISP) & Model 3 (IMSP) & Model 4 (IMSP) \\
\hline c & $\begin{array}{c}-1.3754^{* *} \\
(-2.18)\end{array}$ & $\begin{array}{c}-5.5539 * * \\
(-2.82)\end{array}$ & $\begin{array}{c}-1.1696 \\
(-0.6)\end{array}$ & $\begin{array}{c}-5.3618^{* * *} \\
(2.77)\end{array}$ \\
\hline $\mathrm{ER}_{1}$ & $\begin{array}{c}-31.3891^{* * *} \\
(-4.26)\end{array}$ & & $\begin{array}{c}-35.2783^{* * *} \\
(-4.4)\end{array}$ & \\
\hline $\mathrm{ER}_{1}{ }^{2}$ & $\begin{array}{c}303.0909 * * * \\
(3.34)\end{array}$ & & $\begin{array}{c}308.3838^{* * *} \\
(3.47)\end{array}$ & \\
\hline $\mathrm{ER}_{1}{ }^{3}$ & $\begin{array}{c}-843.9578^{* * *} \\
(-2.68)\end{array}$ & & $\begin{array}{c}-862.6848^{* * *} \\
(-2.79)\end{array}$ & \\
\hline LnED & $\begin{array}{c}1.2451^{* * *} \\
(8.33)\end{array}$ & $\begin{array}{c}1.2455^{* * *} \\
(7.28)\end{array}$ & $\begin{array}{c}1.2308^{* * *} \\
(8.41)\end{array}$ & $\begin{array}{c}1.2329 * * * \\
(7.32)\end{array}$ \\
\hline LnH & $\begin{array}{c}1.4166 \\
(1.5)\end{array}$ & $\begin{array}{c}3.1405^{* *} \\
(3.22)\end{array}$ & $\begin{array}{l}1.3132 \\
(1.42)\end{array}$ & $\begin{array}{c}3.0387^{* *} \\
(3.16)\end{array}$ \\
\hline SIZE & $\begin{array}{c}-0.1702 \text { ** } \\
(-6.49)\end{array}$ & $\begin{array}{c}-0.1885 * * \\
(-6.46)\end{array}$ & $\begin{array}{c}-0.1662 * * * \\
(-6.46)\end{array}$ & $\begin{array}{c}-0.1850 \text { ** } \\
(-6.44)\end{array}$ \\
\hline $\mathrm{ER}_{2}$ & & $\begin{array}{c}-2.5761 * \\
(-1.76)\end{array}$ & & $\begin{array}{c}-2.5342 * \\
(-1.75)\end{array}$ \\
\hline $\mathrm{ER}_{2}{ }^{2}$ & & $\begin{array}{l}5.4757 \\
(1.47)\end{array}$ & & $\begin{array}{l}5.3822 \\
(1.47)\end{array}$ \\
\hline $\mathrm{ER}_{2}{ }^{3}$ & & $\begin{array}{l}-3.1921 \\
(-1.24)\end{array}$ & & $\begin{array}{l}-3.1359 \\
(-1.24)\end{array}$ \\
\hline$R^{2}$ & 0.7652 & 0.7241 & 0.7673 & 0.7240 \\
\hline F Test & $56.48^{* * *}$ & $45.50^{* * *}$ & $57.16^{* * *}$ & $45.46^{* * *}$ \\
\hline$p$-Value & 0 & 0 & 0 & 0 \\
\hline Inflection Point & 0.0757 & 0.3311 & 0.2460 & 0.3314 \\
\hline Value & 0.1637 & 0.8125 & 0.4843 & 0.8128 \\
\hline
\end{tabular}

Note: ${ }^{*}{ }^{* *}, * * *$ express significance at the $10 \%, 5 \%$, and $1 \%$ level, respectively; the value inside parentheses is the $T$ value; the unit of the inflection point value is $\%$.

The comparison of regional and national empirical results shows that the inflection point of environmental regulation in the Bohai Rim region is higher than that of the provincial analysis throughout the country. The Pan-Yangtze River Delta and Pan-Pearl River Delta regions have lower inflection points than the provincial level.

All the models show that the regional development level (LnED) has a positive effect on international R\&D spillover in the control variables, indicating that the awareness of environmental protection by enterprises and residents is higher in the regions of high economic development. In these regions, it is also easier to implement policies related to environmental regulation, which is conducive to stimulating innovation in international trade. For the three major economic regions, human capital $(\mathrm{LnH})$ can also significantly promote the international $\mathrm{R} \& \mathrm{D}$ overflow level. The scale of enterprises (SIZE) has a significant negative effect on the technology spillovers in international trade, indicating that for both provincial and sub-regional studies, there is a negative effect on productivity. 
Table 5. The Pan-Pearl River Delta region's results.

\begin{tabular}{|c|c|c|c|c|}
\hline Variable & Model 1 (FDISP) & Model 2 (FDISP) & Model 3 (IMSP) & Model 4 (IMSP) \\
\hline c & $\begin{array}{l}0.5192 \\
(0.28)\end{array}$ & $\begin{array}{l}0.7597 \\
(-0.36)\end{array}$ & $\begin{array}{l}0.4562 \\
(0.26)\end{array}$ & $\begin{array}{c}-5.3618 * * * \\
(2.77)\end{array}$ \\
\hline $\mathbf{E R}_{1}$ & $\begin{array}{c}-63.4892^{* * *} \\
(-6.35)\end{array}$ & & $\begin{array}{c}-61.4629^{* * *} \\
(-6.32)\end{array}$ & \\
\hline $\mathrm{ER}_{1}{ }^{2}$ & $\begin{array}{c}792.7665^{* * * *} \\
(6.12)\end{array}$ & & $\begin{array}{c}760.68222^{* * *} \\
(6.03)\end{array}$ & \\
\hline $\mathrm{ER}_{1}{ }^{3}$ & $\begin{array}{c}-2738.951 \\
(-5.64)\end{array}$ & & $\begin{array}{c}-2616.8977^{* * * *} \\
(-5.53)\end{array}$ & \\
\hline LnED & $\begin{array}{c}0.5290^{* * *} \\
(4.96)\end{array}$ & $\begin{array}{c}0.7543^{* * *} \\
(4.96)\end{array}$ & $\begin{array}{c}0.5209^{* * *} \\
(3.66)\end{array}$ & $\begin{array}{c}0.7507^{* * *} \\
(5.08)\end{array}$ \\
\hline LnH & $\begin{array}{l}0.1367 \\
(0.13)\end{array}$ & $\begin{array}{l}0.1367 \\
(0.13)\end{array}$ & $\begin{array}{c}0.8313 \\
(0.97)\end{array}$ & $\begin{array}{c}0.1936 \\
(0.2)\end{array}$ \\
\hline SIZE & $\begin{array}{c}-0.0282495 \\
(-0.49)\end{array}$ & $\begin{array}{c}-0.0282495 \\
(-0.49)\end{array}$ & $\begin{array}{c}-0.1347^{* * * *} \\
(-2.92)\end{array}$ & $\begin{array}{c}-0.0309 \\
(-0.55)\end{array}$ \\
\hline $\mathrm{ER}_{2}$ & & $\begin{array}{c}-5.8650 * * \\
(-2.14)\end{array}$ & & $\begin{array}{c}-5.9937^{* *} \\
(-2.26)\end{array}$ \\
\hline $\mathrm{ER}_{2}{ }^{2}$ & & $\begin{array}{c}24.0966 * \\
(1.77)\end{array}$ & & $\begin{array}{c}25.1676 \text { * } \\
(1.90)\end{array}$ \\
\hline $\mathrm{ER}_{2}{ }^{3}$ & & $\begin{array}{c}-28.6136 \\
(-1.55)\end{array}$ & & $\begin{array}{c}-30.1374 \text { * } \\
(-1.68)\end{array}$ \\
\hline$R^{2}$ & 0.6201 & 0.5028 & 0.6262 & 0.5140 \\
\hline F Test & $31.29 * * *$ & $19.38^{* * *}$ & $32.11^{* * *}$ & $20.27^{* * *}$ \\
\hline$p$-Value & 0 & 0 & 0 & 0 \\
\hline Inflection Point & 0.0567 & 0.1784 & 0.0574 & 0.1726 \\
\hline Value & 0.1363 & 0.3831 & 0.1364 & 0.3842 \\
\hline
\end{tabular}

Note: $* * *, * * *$ express significance at the $10 \%, 5 \%$, and $1 \%$ level, respectively; the value inside parentheses is the $T$ value; the unit of the inflection point value is $\%$.

\section{Conclusions and Policy Suggestion}

By analyzing the data of 30 Chinese provinces from 2003 to 2015, a panel data metering model was constructed, the impact of environmental regulation on international R\&D spillover in China was examined, and the impact on China's three major economic regions (Bohai Rim, Pan-Yangtze River Delta, and Pan-Pearl River Delta regions) was further studied. The following conclusions are drawn. Firstly, the relationship between the international technology spillovers and the environmental regulation is observed a variation from positive to negative, which is represented significantly as an inverted N-typed curve: With the increasing intensity of environmental regulation, the trend in the level of international R\&D spillover decreases, increases, and then decreases. Environmental regulation has the best reasonable range. Within this interval, environmental regulation promotes technological innovation, the transfer of international high-tech environmental technologies, and regional sustainable development. Secondly, the use of different environmental regulations affects the international R\&D spillover and environmental regulation's inverted N-curve relationship, changing the inflection point of environmental regulation. Thirdly, at present, the level of environmental regulation in most Chinese provinces is at the first turning point, which indicates that the level of environmental regulation in these areas is still relatively low, which is not conducive to the transformation of international technology in the region. The government should appropriately increase the intensity of environmental regulation to stimulate technological innovation in China, and accelerate the development of new energy-saving and environmentally friendly technologies, and promote regional sustainable development with less energy consumption and pollution emissions. Fourth, the regional research shows that some 
differences remain among the Bohai Rim, Pan-Yangtze River Delta, and the Pan-Pearl River Delta regions, so when developing environmental regulation policy, the government should adapt to local conditions, consider the tolerance capacity of the region, choose the appropriate environmental regulatory intensity, and develop appropriate environmental regulation policies for each region. The government should seek the sustainable development of the economy, resources, and society on the basis of fully understanding regional differences.

Based on the above conclusions, we think that to promote the international R\&D results in China and upgrade innovation-driven industrial transformation based on long-term sustainable development strategy, we can proceed in the following aspects. First, the government should rationally develop the intensity of environmental regulation in China, not only to stimulate pollution control innovation in enterprises to achieve energy conservation, pollution control, and enhance sustainability, but also to stimulate enterprises to further absorb international technology spillovers, to conduct technological innovation, and to improve the international competitiveness of enterprises. However, in the long term, overly strict environmental regulation will inhibit the adsorption of international technology in the domestic transformation, which will not be conducive to regional sustainable development. Secondly, the government should rationally use environmental regulation. The impact of environmental regulation on the level of international R\&D spillover is not only related to the intensity of environmental regulation but also to the form of environmental regulation adopted by the government. Given China's current situation, the government should use a variety of flexible policies to break through the first turning point of environmental regulation and ensure the significance of the ascending stage to provide a long-term sustainable development mechanism for increasing the quality and strengthening the efficiency of the Chinese economy.

Author Contributions: C.L. developed the original idea of this study and performed the data analysis, T.W. revised the manuscript. Q.G. supervised the research project and drafted the original manuscript. All authors read and approved the final manuscript.

Funding: This research was funded by the National Nature Science Foundation of China, grant number 41571123, the National Social Science Fund of China, grant number 18BJL056, the Research Initiation Fund of Hainan University, grant number kyqdsk201903, the Shanghai Pujiang Program, grant number 17PJC030 and the Strategic Priority Research Program of the Chinese Academy of Sciences, grant number XDA20100311.

Acknowledgments: We are grateful for Qi Liu portraying the figures and tables. empirical research.

Conflicts of Interest: The authors declare no conflict of interest.

\section{References}

1. Long, X.L.; Naminse, E.Y.; Du, J.G.; Zhuang, J.C. Nonrenwable energy, renewable energy, carbon dioxide emissions and economic growth in China from 1952 to 2012. Renew. Sustain. Energy Rev. 2015, 52, 680-688. [CrossRef]

2. Jalil, A.; Feridun, M. The impact of growth, energy and financial development on the environment in China: A cointegration analysis. Energy Econ. 2011, 33, 284-291. [CrossRef]

3. Sarkodie, S.A.; Strezov, V. Empirical study of the environmental Kuznets curve and environmental sustainability curve hypothesis for Australia, China, Ghana and USA. J. Clean. Prod. 2018, 201, 98-110. [CrossRef]

4. Mangra, M.G.; Cotoc, E.A.; Traistaru, A. Sustainable economic development through environmental management systems implementation. J. Stud. Soc. Sci. 2014, 6, 1-14.

5. Westman, L.; Broto, V.C. Climate governance through partnerships: A study of 150 urban initiatives in China. Glob. Environ. Change 2018, 50, 212-221. [CrossRef]

6. Vona, F.; Marin, G.; Consoli, D.; Popp, D. Environmenal regulation and green skills: An empirical exploration. J. Assoc. Environ. Resour. Econ. 2018, 5, 713-753.

7. Sueyoshi, T.; Yuan, Y. Social sustainability measured by intermediate approach for DEA environmental assessment: Chinese regional planning for economic development and pollution prevention. Energy Econ. 2017, 66, 154-166. [CrossRef] 
8. Yuan, B.L.; Xiang, Q.L. Environmental regulation, industrial innovation and green development of Chinese manufacturing: Based on and extended CDM model. J. Clean. Prod. 2018, 176, 895-908. [CrossRef]

9. Liu, J.P.; Lu, K.; Cheng, S.X. International R\&D spillovers and innovation efficiency. Sustainability 2018, 10, 3974. [CrossRef]

10. Wanlley, W. The contribution of environmental regulations to slowdown in productivity growth. J. Environ. Manag. 1994, 8, 381-390.

11. Poter, M.E.; Linde, C.V. Toward a new conception of the environment competitiveness relationship. J. Econ. Perspect. 1995, 9, 97-118. [CrossRef]

12. Ambec, S.; Cohen, M.A.; Elgie, S.; Lanoie, P. The porter hypothesis at 20: Can environmental regulation enhance innovation and competitiveness. Rev. Environ. Econ. Policy 2013, 7, 2-22. [CrossRef]

13. Han, X.F.; Hui, N.; Song, W.F. Environmental regulation's influential effect on R\&D technological progress. Forum Sci. Technol. 2014, 12, 75-79. (In Chinese)

14. Chakraborty, P.; Chatterjee, C. Does environmental regulation indirectly induce upstream innovation? New evidence from India. Res. Policy 2017, 46, 939-955. [CrossRef]

15. Jaffe, A.B.; Palmer, K. Environmental regulation and innovation: A panel data study. Rev. Econ. Stat. 1997, 79, 610-619. [CrossRef]

16. Ma, F.P.; Cha, N. The impact of environmental regulation on technological innovation performance: The moderating role of institutional environment. RED Manag. 2012, 1, 60-66. (In Chinese)

17. Dechezlepretre, A.; Sato, M. The impacts of environmental regulations on competitiveness. Rev. Environ. Econ. Policy 2017, 11, 183-206. [CrossRef]

18. Guo, Y.Y.; Xia, X.N.; Sheng, Z.; Zhang, D.P. Environmental regulation, goverment R\&D funding and green technology innovation: Evidence from China provincial data. Sustainability 2018, 10, 940. [CrossRef]

19. Cohen, M.A.; Tubb, A. The impact of environmental regulation on firm and country competitiveness: A meta-analysis of the Porter hypothesis. J. Assoc. Environ. Resour. Econ. 2018, 5, 371-399. [CrossRef]

20. Coe, D.T.; Helpman, E. International R\&D spillovers. Eur. Econ. Rev. 1995, 53, 723-741.

21. Madsen, J.B. Technology spillover through trade and TFP convergence: 135 years of evidence for the OECD countries. J. Int. Econ. 2007, 72, 464-480. [CrossRef]

22. Javorcik, B.S. Does foreign direct investment increase the productivity of domestic firms? In search of spillovers through backward linkages. Am. Econ. Rev. 2004, 94, 605-627. [CrossRef]

23. Krammer, S.M. International R\&D spillovers in emerging markets: The impact of trade and foreign direct investment. J. Int. Trade Econ. 2010, 19, 591-623.

24. Hassine, B.; Boudier, F.; Mathieu, C. The two ways of FDI R\&D spillovers: Evidence from the French manufacturing industry. Appl. Econ. 2017, 49, 2395-2408.

25. Zhuang, H.M.; Zheng, J.S. Research on the effect of FDI in China's service industry. Manag. Rev. 2015, $27,26$. (In Chinese)

26. Aldieri, L.; Sena, V.; Vinci, C.P. Domestic R\&D spillovers and absorptive capacity: Some evidence for US, Europe and Japan. Int. J. Prod. Econ. 2018, 198, 38-49.

27. Lee, D. The role of $R \& D$ and input trade in productivity growth: Innovation and technology spillovers. J. Technol. Transf. 2019, 1, 1-21.

28. Hanna, R. US environmental regulation and FDI: Evidence from a panel of US-based multionational firms. Am. Econ. J. Appl. Econ. 2010, 2, 158-189. [CrossRef]

29. Chung, S.H. Environmental regulation and foreign direct investment: Evidence from South Korea. J. Dev. Econ. 2014, 108, 222-236. [CrossRef]

30. Tsurumi, T.; Managi, S.; Hibiki, A. Do environmental regulations increase bilateral trade flows? BE J. Econ. Anal. Policy 2015, 15, 1549-1577. [CrossRef]

31. Mualtu, A. The structure of UK outbound FDI and environmental regulation. Environ. Resour. Econ. 2017, 68, 65-96. [CrossRef]

32. Ramzy, M.; Zaki, C. Do environment regulations matter for EU-MENA trade? Appl. Econ. 2018, 50, 1549-1577. [CrossRef]

33. Lichtenberg, F.R.; Potterie, B.P. International R\&D spillovers: A comment. Eur. Econ. Rev. 1998, 42, $1483-1491$.

34. Weil, D.N. Capital and wealth in the twenty-first century. Am. Econ. Rev. 2015, 105, 34-37. [CrossRef] 
35. Berlemann, M.; Wesselhoft, J.E. Estimating aggregate capital stocks using the perpetual inventory method: A survey of previous implementations and new empirical evidence for 103 countries. Rev. Econ. 2016, 65, 1-34. [CrossRef]

36. Ryan, S.P. The costs of environmental regulation in a concentrated industry. Econometrica 2012, 80, $1019-1061$.

37. Rubashkina, Y.; Galeotti, M.; Verdolini, E. Environmental regulation and competitiveness: Empirical evidence on the porter hypothesis from European manufacturing sectors. Energy Policy 2015, 83, 288-300. [CrossRef]

38. Yin, J.H.; Zheng, M.Z.; Chen, J. The effects of environmental regulation and technical progress on $\mathrm{CO}_{2}$ Kuznets curve: An evidence from China. Energy Policy 2015, 77, 97-108. [CrossRef]

39. Zivin, J.G.; Neidell, M. Environment, health, and human capital. J. Econ. Lit. 2013, 51, 689-730. [CrossRef]

40. Zhan, H.; Yu, J.P. An Empirical Study on the Impact of Trade Opening on Environmental Pollution in China. Mod. Econ. Sci. 2015, 37, 39-46. (In Chinese)

(C) 2019 by the authors. Licensee MDPI, Basel, Switzerland. This article is an open access article distributed under the terms and conditions of the Creative Commons Attribution (CC BY) license (http://creativecommons.org/licenses/by/4.0/). 